\title{
The Metadiscourse Markers in Good Undergraduate Writers' Essays Corpus
}

\author{
Amaal Fadhlini Binti Mohamed ${ }^{1} \&$ Radzuwan Bin Ab Rashid ${ }^{1}$ \\ ${ }^{1}$ Faculty of Languages and Communication, Universiti Sultan Zainal Abidin, 21030 Kuala Nerus, Terengganu, \\ Malaysia \\ Correspondence: Radzuwan Ab Rashid, Office of Deputy Dean of Research and Development, Faculty of \\ Languages and Communication, Universiti Sultan Zainal Abidin, 21030 Kuala Nerus, Terengganu, Malaysia. \\ E-mail: radzuwanrashid@unisza.edu.my
}

Received: June 12, 2017 Accepted: July 10, 2017 Online Published: October 11, 2017

doi:10.5539/ijel.v7n6p213 URL: http://doi.org/10.5539/ijel.v7n6p213

\begin{abstract}
Good student writers are often seen as a benchmark to the weaker writers. In the area of metadiscourse in students' writing, previous studies show that good undergraduate writers use more metadiscourse markers as compared to the weaker writers. However, there are limited previous studies which observe the use of metadiscourse among Malaysian ESL undergraduate writers whose Bahasa Malaysia is their first language. Therefore, further studies involving undergraduate writers from this particular setting is significant to add more literature to the field of metadiscourse among ESL undergraduates. This paper aims to present the metadiscourse markers found in a corpus of good undergraduate writers' essays (GUWE corpus). These metadiscourse markers are classified in the main categories and sub-categories based on Hyland's (2005) interpersonal model of metadiscourse. Using a concordance software, this study aims to reveal the frequency of the metadiscourse markers use in good essays produced by 269 Malaysian undergraduate writers. The findings presented in this paper are hoped to be useful for other researchers who are interested in the same field of metadiscourse among ESL student writers especially among Malaysian undegraduates.
\end{abstract}

Keywords: good essays, interactive metadiscourse, interactional metadiscourse, Malaysian undergraduates, ESL writers' essays

\section{Introduction}

\subsection{Undergraduates' Essay Writing and Metadiscourse}

Nowadays, the ability to write effectively among undergraduates has become significant at the tertiary education level. Throughout their undergraduate programme, they have to write many types of writing including reports, essays, summaries and so on. These types of writing are assessed and awarded with marks to determine the quality. Thus, among undergraduates, improving their writing quality has become a part of their learning progress.

As English as a Second Language learners, undergraduates in Malaysia have to enrol an English language class every semester for the period of at least one year to two years of studying. In this class, they are taught to write many types of essay writing especially persuasive and argumentative essays. Persuasive writing, for example, determines the success in language among students at school because the students have to give reasoning and supportive arguments in their essays (Rustipa, 2014). Therefore, students write their essays with cautiousness to structure their sentences and put words together to convey their ideas clearly. One of the ways is to use metadiscourse in their writing.

Metadiscourse is defined as indicating words of any interactions between writers to readers and writers to themselves which is not a part of contents in the text (depending on the writers' meaning) to deliver and organise contents or messages effectively. The examples of metadiscourse markers in undergraduate essays are underlined in the following sentences.

-They will also suffer from poor self-esteem and lack of self-confidence.

-As an example, medical course is very important because a doctor is needed in our life. 
-So, this course, money management course can help the student on how to organize their money correctly.

-So, I think it is not necessary to make financial or money management courses compulsory for all university students.

-As we all know, most of university students still in the range of teenagers which is at this stage, they love to experience new things.

-So, think about it!

\subsection{Metadiscourse}

Metadiscourse has been expansively introduced as "writing about writing" (Williams, 1985, p. 226) which refers to any writer and speaker's linguistic expressions while interacting with the readers and listeners. This definition of metadiscourse always develops as the number of studies rises. Metadiscourse includes some linguistic expressions in a text which explains on the text itself, rather than of its propositional content (Thompson, 2003). Later, Hyland (2005) introduces metadiscourse as a "social and communicative process" between writers and their readers (p. 14).

Writers provide "cues and indicators" in their writing while arranging the contents to help readers comprehend and respond to the text (Kumpf, 2000, p. 401). In fact, these "cues and indicators" mean what Hyland (2004, p. 142 ; 2005, p. 50) mentions as "metadiscourse markers". Jalilifar \& Alipour (2007) suggest that these metadiscourse markers organise contents of a text and messages by using connectives and form an interaction between the writers and readers to become more reader-friendly texts. The same idea has also been proposed earlier by Vande Kopple (1985).

As writing is viewed as a social engagement in which writers interact with their readers to convey messages (Amiryousefi \& Rasekh, 2010; Rashid, Rahman, \& Rahman, 2016), metadiscourse helps the readers to understand the messages in text. By using metadiscourse effectively in writing, the messages can clearly be conveyed to the readers. Previous studies have revealed that metadiscourse makes writing more effective as the ideas in the text become more organised, clear and understandable (Intaraprawat \& Steffensen, 1995; Hyland, 2005; Amiryousefi \& Rasekh, 2010).

\subsection{Hyland's (2005) Interpersonal Model of Metadiscourse}

As cited in Hyland (2005), the term metadiscourse was first introduced by Harris (1959) referring to a system of language comprehension in use to demonstrate a writer's attempts in guiding the reader's perception toward the messages in a text. Metadiscourse is also broadly defined as "discourse about discoursing" (Vande Kopple, 1985, p. 83; Beauvais, 1989, p. 11) which refers to the writer's or speaker's linguistic expressions to unite with the readers or listeners. In fact, Crismore, Markkanen, and Steffensen (1993) stated that anything which does not add anything to the proposional content in the text is known as metadiscourse.

There are a number of different ways which metadiscourse markers have been categorised. In the present study, Hyland's interpersonal model of metadiscourse (2005) is used as it provides comprehensive categories and sub-categories of metadiscourse. In this classification model of metadiscourse, the metadiscourse markers are classified into two main categories (interactive and interactional metadiscourse) and sub-categories, such as transitions, endophoric markers, frame markers, evidential, code glosses, hedges, attitude markers, boosters, engagements markers and self-mentions.

Hyland (2005) introduces an interpersonal model of metadiscourse to analyse the metadiscourse used in academic text, as shown in Table 1. In his study conducted in 2004, the scheme is known as a model of metadiscourse in academic texts which is similar to the latest scheme introduced in 2005. Hence, the latest scheme comes with a list of possible metadiscourse markers (498 markers) as reference to spot metadiscourse expressions in text. The scheme is divided into two terms of main categories which are "interactive" and "interactional" metadiscourse. This model was used as a guideline to analyse metadiscourse markers found in this present study. 
Table 1. An interpersonal model of metadiscourse (Hyland, 2005, p. 49)

\begin{tabular}{lll}
\hline \multicolumn{1}{c}{ Category } & Function & Examples \\
\hline $\begin{array}{l}\text { Interactive resources: Help to guide reader through the text } \\
\text { Transitions }\end{array}$ & Express semantic relation between main clauses & In addition/ but/ thus/ and \\
$\begin{array}{l}\text { Frame markers } \\
\text { Endophoric markers }\end{array}$ & Refer to discourse acts, sequence, or text stages & Finally/to conclude/my purpose here is to \\
Evidentials & Refer to information in other parts of the text & Noted above/ see Fig/ in section 2 \\
Code glosses & Refer to source of information from other texts & According to x/ (Y, 1990)/ Z states \\
Interactional resources: Involve the reader in the argument & Namely/ e.g./ such as/ in other words \\
$\begin{array}{l}\text { Hedges } \\
\text { Boosters }\end{array}$ & Withhold writer's full commitment to proposition & Might/ perhaps/ possible/ about \\
Attitude markers & Emphasize force or writer's certainty in proposition & In fact/ definitely/ it is clear that \\
Engagement markers & Express writer's attitude to proposition & Unfortunately/ I agree/ surprisingly \\
Self-mentions & Explicitly refer to or build relationship with reader & Consider/ note that/ you can see that \\
\hline
\end{tabular}

According to Hyland (2005, p. 49), interactive resources "help to guide the reader through text". The metadiscourse markers in interactive resources category are the indicators used by writers to assist and direct their readers to understand the messages while reading the text. The first sub-category in interactive resources is transitions which highlight the relationship between the meanings of main clauses in the text such as in addition, but, thus, and, and so on. The second sub-category is frame markers which include signalling words to indicate numbering order, sequence or stages in the text, such as firstly, finally, in conclusion, in the nut shell and so on. These markers also include announcing phrases that highlight the stages in the writing such as now you have to and my purpose here is to.

The next sub-category is the endophoric markers which refer to any information the writer has stated previously anywhere in the text, such as noted above that, see Figure 2 and in the earlier section. Another sub-category in interactive resources is evidentials. Some types of writing do not include this sub-category because it is guiding the reader to refer to the information from other sources, such as according to Swales, (Hunston, 1996) and Jones states that. The final sub-category of interactive resources is code glosses which "help readers grasp functions of ideational material" (Hyland, 2005, p. 49). The markers include signalling words like namely, for example, such as and in other words.

Another main category is interactional resources which "involve the reader in the argument" (Hyland, 2005, p. 49). The metadiscourse markers in this category includes the signalling words and phrases which are purposely written to engage with the readers or attract the readers to take part in any arguments of the text. These markers includes hedges which work as a linguistic shield to hold back what is said by the writer, such as the modals might, may, and should. Hedges in metadiscourse also include other signalling words like perhaps, possible, possibly, and about. The next sub-category is known as boosters which stress on the confidence of writers' proposition such as the markers definitely, in fact, it is clear that and it is confirmed that.

Attitude markers is another sub-category which refers to the metadiscourse markers that highlight a writer's feeling and attitude towards what he or she is saying in the writing. The markers include unfortunately, surprisingly, and I agree. Another sub-category is engagement markers. They are called engagement markers because these words or phrases are used to engage with the readers, such as note that, you can see that, and consider. The final sub-category in interactional resources is self-mentions which directly announce the author of the text by using pronouns like $I$, we, $m y$, and our.

Hyland (1998) enriches Crismore et al.'s taxonomy (1993) by reducing its categories and curtailing the overlapped functions. The interpretive markers category is removed and the main categories (textual metadiscourse and interpersonal metadiscourse) stay. In other words, Hyland's $(2004,2005)$ changes the name of the two main categories into interactive and interactional metadiscourse categories.

Although Hyland (2005) has listed 498 possible metadiscourse markers in academic text, only some are commonly used by writers especially the inexperienced undergraduate writers. One possible marker might be a metadiscourse marker in a sentence, but might also work as a propositional content in another sentence. It depends on the meaning which a particular writer or speaker is trying to convey. So this list is very useful to help researchers in searching for metadiscourse markers in their writing samples, especially in large samples.

\subsection{Problem Statement}

Some previous studies evidenced that good essays contain more metadiscourse than weak essays (e.g., 
Intaraprawat \& Steffensen, 1995; Jalilifar \& Alipour, 2007). This becomes the reason why the present study focuses on the good essays for more metadiscourse markers to be analysed. There are also limited previous studies which examined metadiscourse use among Malaysian ESL undergraduate writers whose Bahasa Malaysia is their first language. So this study is useful to fill in the gap in the literature.

\subsection{Research Questions}

There is a dynamic need to explore how Malaysian ESL undergraduate writers use metadiscourse markers in their writing in order to deliver contents clearly and effectively. This study aims to present the detailed results of the metadiscourse markers use among a large group of undergraduate writers based on their good written essays. These results will lead to further analysis in investigating the current understanding on metadiscourse among similar group of writers.

The research questions guiding this study are:

1) What are the frequencies of metadiscourse markers use in both interactive and interactional metadiscourse in good undergraduate writers' essays?

2) What are the metadiscourse markers identified in good undergraduate writers' essays and how are these metadiscourse markers classified into main categories and sub-categories?

\section{Method}

\subsection{Samples}

The samples came from undergraduate writers who enrolled in two foundation programmes which are Asasi Science and Asasi Engineering at a local public university in Malaysia. It is the final semester as a foundation programme is only a one-year-programme, which is generally enrolled by excellent students who receive good results in the Sijil Pelajaran Malaysia (the Malaysian Certificate of Education).

A collection of good undergraduate writers' essays from Science and Engineering fields in Malaysia was composed from 269 students yielding a total number of 143, 407 words. These writing samples were taken from the writing section of their final examination answer scripts for English course at the end of semester two. They had to write a persuasive essay with the length of approximately 350 words. That means these essays were written by these undergraduate students as a part of their final examination answer scripts. The topic of these essays are similar which requires the students to agree or disagree if financial management course is made compulsory to all university students.

These essays were selected as samples because they obtained high marks as awarded by their respective lecturers. The full marks for each essay are 30 marks. So the good essays are among the essays who received 20 and above, based on the teacher's marking scheme. Based on the scheme, the good essays are clear and show accurate presentation while showing full control of the language. These essays convey message clearly and use discourse markers confidently to show the flow of thought. There are no obvious mistakes in word choice and they show good organisation of main themes and supporting details.

\subsection{Corpus}

This collection of essays were converted into an electronic corpus and named as GUWE corpus. The metadiscourse markers in the corpus were electronically searched with an assistance of a concordance computer programme, WordSmith. The list of 498 metadiscourse markers (Hyland, 2005) was used to match any hits in the corpus. Only sentences which appeared to have metadiscourse markers were thoroughly analysed and classified into the different metadiscourse categories. Two experienced readers from the field of English Language were involved during a few sessions of metadiscourse markers identification. They were important spectators who act as a second and third person to check the metadiscourse markers found, whether one particular marker is categorically a metadiscourse marker. Any issues were thoroughly discussed for validity and transferability of the findings in this study. For example, transition marker "and" is categorised as a metadiscourse marker when it is connecting two or more ideas or clauses in a sentence. With the support of software analysis, occurrence per 10,000 words of each metadiscourse marker found was calculated to find the most shared metadiscourse markers and categories involved in GUWE corpus based on Hyland's interpersonal model of metadiscourse (2005). The GUWE corpus of 143,407 words was also searched sentence by sentence to find possible metadiscourse markers in the whole MicrosoftWord file to find more metadiscourse markers who are not listed on the list of 498 metadiscourse markers (Hyland, 2005). These markers become significant markers found in this corpus. 


\section{Findings}

3.1 Answering Research Question 1: What Are the Frequencies of Metadiscourse Markers Use in Both Interactive and Interactional Metadiscourse in Good Undergraduate Writers' Essays?

The frequency of two main categories of metadiscourse in GUWE corpus was electronically and manually counted. It is found that the total hits of interactive metadiscourse markers are 6,740 while the total hits of interactional metadiscourse markers are 5,286. The frequency of use of interactive and interactional metadiscourse is presented in Table 2 .

Table 2. Frequency of use of interactive and interactional metadiscourse

\begin{tabular}{llll}
\hline & \multicolumn{3}{c}{ GUWE corpus $(143,407$ words $)$} \\
\hline Metadiscourse Category & Total Markers & Occurrence per 10,000 words & \% of Total metadiscourse \\
Interactive & 6,740 & 467.48 & 55.91 \\
Interactional & 5,286 & 368.60 & 44.09 \\
Total & 11,990 & 836.08 & 100 \\
\hline
\end{tabular}

Based on the findings in GUWE corpus, it can be seen that interactive metadiscourse has a higher frequency of use with 467.48 occurrences per 10,000 words as compared to interactional metadiscourse with 368.60 occurrences per 10,000 words. Interactive metadiscourse use is recorded as $55.91 \%$, while interactional metadiscourse use is $44.09 \%$ ( $11.82 \%$ lower than Interactive metadiscourse). The percentage gap of total metadiscourse is over 10 percent. At this point, the finding is similar to several other metadiscourse studies, such as Intaraprawat \& Steffensen (1995), Jalilifar \& Alipour (2007) and Rustipa (2014), which show the use of interactive metadiscourse is higher than interactional metadiscourse. That is to say that interactive metadiscourse is often used throughout the text because it leads the readers to comprehension level with the assistance of transition markers, frame markers, endophoric markers, evidentials and code glosses. However, these findings are different from the findings revealed by Heng \& Tan (2010) which show that interactional metadiscourse is higher than interactive metadiscourse. They studied the essays among good students who are Malaysian undergraduates from another public university. This suggests that the use of metadicourse is influenced by the learners' background. The samples are among good students who are enrolling a bachelor's degree programme.

The frequency use of interactional metadiscourse in GUWE corpus is lower because it involves skills of the writer in engaging himself with the readers by drawing them into the discussion of the text. The writer would use hedges, engagement markers, boosters, self-mention and attitude markers to attract the readers' participation while they are reading the text. So the use of effective interactional metadiscourse generally depends on the writers' writing skill. In a corpus of leading journal articles of various fields studied by Hyland (1998), the writers show the use of logical connectives, endophoric markers, frame markers, code glosses and evidential (55.1\% of total metadiscourse) and emphatics, hedges, relational markers, attitude markers and person markers ( $44.9 \%$ of total metadiscourse). The percentage gap is fairly small. In regard to these findings, experienced writers are expectedly writing with more interactional metadiscourse as compared to inexperienced writers, especially undergraduates.

The next stage of analysis involved the frequency count of metadiscourse use in GUWE corpus based on each sub-category of metadiscourse. Table 3 presents the analysis of interactive metadiscourse found.

Table 3. Categories of interactive metadiscourse found in GUWE corpus

\begin{tabular}{llll}
\hline \multicolumn{3}{c}{ GUWE corpus $(143,407$ words $)$} \\
\hline Metadiscourse Category & Total Markers & Occurrence per 10, 000 words & \% of Total metadiscourse \\
1. Interactive & & & \\
Transitions & 5,365 & 374.11 & 80.03 \\
Code Glosses & 704 & 49.09 & 10.50 \\
Frame Markers & 600 & 41.84 & 8.95 \\
Endophoric Markers & 20 & 1.39 & 0.30 \\
Evidentials & 15 & 1.05 & 0.22 \\
\hline Total & 6,704 & & 100 \\
\hline
\end{tabular}

Table 3 shows that transitions (e.g., and, also, but) has the highest frequency count of its use in GUWE corpus with more than half of the total metadiscourse which is 80 percent as it scores 5,365 markers. These markers are 
mostly used in any essay because they highlight the relationship between the sentences in the text. Using transitions is the easiest way to organise sentences. The code glosses like "such as, for example and this means" (occurrence per 10,000 words) are used more than frame markers (e.g., firstly, in conclusion, then) with 704 code glosses (49.09 occurrence per 10, 000 words) and 600 frame markers (41.84 occurrence per 10,000 words).

On the other hand, endophoric markers and evidentials register the lowest frequency count of use in this corpus. Endophoric markers (e.g., $X$ above, $X$ before, $X$ earlier) account for only 1.39 occurrences per 10, 000 words. Meanwhile, evidentials (e.g., quoted) in GUWE corpus show the lowest frequency of use with 1.05 occurrences per 10, 000 words. This is because students, usually, do not use citation in this kind of essay, especially when they are writing without available sources in an examination-oriented setting.

Table 4. Categories of interactional metadiscourse in GUWE corpus

\begin{tabular}{llll}
\hline & \multicolumn{2}{c}{ GUWE corpus $(143,407$ words $)$} \\
\hline Metadiscourse Category & Total Markers & Occurrence per 10,000 words & \% of Total metadiscourse \\
2. Interactional & & & \\
Hedges & 1,719 & 119.87 & 32.52 \\
Engagement Markers & 1,353 & 94.35 & 25.60 \\
Boosters & 1,075 & 74.96 & 20.34 \\
Attitude Markers & 578 & 40.30 & 10.93 \\
Self Mentions & 561 & 39.12 & 10.61 \\
\hline Total & 5,286 & & 100 \\
\hline
\end{tabular}

Similar to interactive metadiscourse category, interactional metadiscourse category has also five sub-categories which are Hedges, Boosters, Attitude markers, Self-mentions and Engagement markers. The table shows that hedges (e.g., should, would, may) has the highest frequency count. The use of hedges is leading with 119.87 occurrences per 10, 000 words. The use of boosters (e.g., strongly, must, really,!) seem to be in the middle with 74.96 occurrences per 10, 000 words The use of attitude markers (e.g.: agree, important,!) is in the second last position with 40.30 occurences per 10, 000 words. Based on percentage, attitude markers seem to have only $0.32 \%$ higher than Self-mentions with both recorded $10.93 \%$ and $10.61 \%$ respectively.

\subsection{Answering Research Question 2: What Are the Metadiscourse Markers Identified in Good Undergraduate Writers' Essays and How Are These Metadiscourse Markers Classified into Main Categories and Sub-categories?}

As the research question is also seeking for the classifications of metadiscourse markers found in GUWE corpus (how are they classified into categories and sub-categories?), the following table shows how the classification of the categories is completed. This information is very important to be revealed in as the other researchers who are interested in the same field of metadiscourse among ESL student writers can benefit from these detailed findings.

Table 5. Metadiscourse markers identified and classified into main categories and sub-categories

\begin{tabular}{|c|c|c|}
\hline Main Categories & Sub-categories & GUWE corpus \\
\hline \multirow{8}{*}{ Interactive } & Transitions & $\begin{array}{l}\text { And (linking two clauses), Also, Because, So, But, Thus, Therefore, Besides, So that, Still, } \\
\text { However, Hence, Moreover, Since, Other than that, In addition, While, Rather, Although, } \\
\text { Again, As a result, On the other hand, Consequently, Yet, Beside that, Result in, Even though, } \\
\text { Furthermore, In contrast, Whereas, Likewise, nevertheless, Though, As a consequence, } \\
\text { Conversely, Nonetheless, So as to, The result is }\end{array}$ \\
\hline & Frame markers & Sequencing \\
\hline & & $\begin{array}{l}\text { Last but not least, Firstly, Lastly, Secondly, Next, Then, First of all, Thirdly, Finally, First, At } \\
\text { first, By, then } \\
\text { Label Stages }\end{array}$ \\
\hline & & $\begin{array}{l}\text { In conclusion, As a conclusion, In a nutshell, Now, In short, To conclude, At this stage, All in } \\
\text { all, Overall, In sum, In brief, At this point of life } \\
\text { Announce goals }\end{array}$ \\
\hline & & $\begin{array}{l}\text { Would like to, There are many reasons, Objective, Purpose, Want to, (in) this part } \\
\text { Shift topic } \\
\text { Now, Back to, Well }\end{array}$ \\
\hline & Endophoric markers & $X$ above, Above $X$, If this happens \\
\hline & Evidentials & Said, According to, quoted \\
\hline & Code glosses & $\begin{array}{l}\text { Such as, For example, That is, For instance, Say, Or X, This can be, } \\
\text { ( ), This means, As an example, Indeed, Which means, Known as, I mean, In contrast, If this } \\
\text { happens, Specifically, That means, In fact, Namely }\end{array}$ \\
\hline
\end{tabular}




\begin{tabular}{|c|c|c|}
\hline \multirow{5}{*}{ Interactional } & Hedges & $\begin{array}{l}\text { Should, Would, May, Could, Tend to, Might, Usually, Feel, Maybe, Sometimes, In my } \\
\text { opinion, Almost, Would not, Quite, Around, Probably, Mostly, Couldn’t, Seems, Supposed, } \\
\text { Possible, Likely, Perhaps, Rather, Mainly, Possibly, Suggest/ed, About, Ought, In my } \\
\text { perspectives, Frequently, From my, Generally, In general, In my view, Apparent, typical, } \\
\text { Unlikely, Argue }\end{array}$ \\
\hline & Boosters & $\begin{array}{l}\text { Think, Really, Must, Always, Strongly, Actually, Know, Find, Realize/d, Sure, In my opinion, } \\
\text { True, Never, Surely, Definitely, Known, Of course, Truly, Highly, In fact, Obviously, Proven, } \\
\text { Certainly, Undeniably, Undeniable, Indeed, Found, Obvious, Believed, Evident, Find, No } \\
\text { doubt, It is shown, Prove, Undoubtedly }\end{array}$ \\
\hline & Attitude markers & $\begin{array}{l}\text { Important, Agree, Even X, Disagree, !, Correctly, Appropriate, Interesting, Essential, } \\
\text { Expected, Importantly, Hopefully, Unexpected, Fortunate, Appropriately, Usual, Surprisingly, } \\
\text { Curious, Dramatic, Must (politeness) }\end{array}$ \\
\hline & Engagement markers & $\begin{array}{l}\text { We (inclusive), Our, ?, Us, We/you have to, We do not, We need to, We can see, As we can } \\
\text { see, Imagine, Do not/ Don't, You choose, Remember, Let, You need to, Think about, Let's, } \\
\text { Look at, By the way, Prepare, You can see }\end{array}$ \\
\hline & Self-mentions & $\mathrm{I}, \mathrm{My}, \mathrm{Me}$ \\
\hline
\end{tabular}

Table 5 shows the detailed findings of metadiscourse markers found in GUWE corpus which consists of 269 essays yielding a total number of 143, 407 words in one corpus. Although Hyland (2005) has listed 498 possible metadiscourse markers in academic text, only some are commonly used by this group of undergraduate writers.

\section{Conclusion and Recommendations}

This study reveals that undergraduates use more interactive metadiscourse. This is perhaps because it leads the readers to understand through the application of transition markers, frame markers, endophoric markers, evidentials and code glosses. In fact, the use of transition markers (but, because, also) and frame markers (first, then, finally) is the easiest way to organise sentences and ideas.

In comparison, the use of interactional metadiscourse in the corpus is lower because it includes ways the writer interacts with the readers by attracting them into the discussion in the text. In this case, these inexperienced writers (undergraduates) would use fewer hedges (claim, could, tend to), boosters (certain, believe, found), engagement markers (note that, refer), attitude markers (expected, important, usually) and self-mention (I, we, us) to attract the readers' participation while reading. The use of interactional metadiscourse depends on the writers' writing skill which most undergraduates do not yet fully master, if their essays are to be compared with the professional writers or native speakers. They are school-leaver-undergraduates who just finished their secondary level of education in less than one year.

In this context, it can be said that interactional metadiscourse is used less by these undergraduates because the nature of the essay which only requires each student to write about 350 words only. There will be more interactional metadiscourse markers if the essays are longer with more discussions and arguments. This is revealed by Heng \& Tan (2010) in their findings which show that MU (Malaysian Undergraduate) corpus contains more interactional metadiscourse markers as compared to interactive metadiscourse markers, which is different from the findings of this study and what other previous researchers normally found. This might be due to the length of the essay samples which are longer. The topic given in their study also required the students to be more critical and argumentative, hence the use of interactional metadiscourse is found more in such corpus.

For extending this study in the future, GUWE corpus is mainly an example of a collection of 269 good undergraduate writers' essays from Science and Engineering fields taken from one particular public university in Malaysia. They are selected as good essays based on the marks awarded by their respective English language teachers/lecturers. It is hoped that more essays can be composed from other fields of various universities in Malaysia to create a prominent collection of undergraduate writers' essays.

It is hoped that this study will help other researchers in comparing their findings of the same area of research. Since this research does not look at the ineffective usage of metadiscourse employed by these undergraduate writers, further studies are recommended to investigate deeper into the inappropriate use of metadiscourse in the undergraduates' academic essays.

\section{Acknowledgments}

Special thanks to Faculty of Languages and Communication, Universiti Sultan Zainal Abidin, Malaysia for the chance and financial supports throughout the journey to complete writing this article. We would like to thank Universiti Malaysia Kelantan for providing other related financial support to finish the study. 


\section{References}

Amiryousefi, M., \& Rasekh, M. (2010). Metadiscourse: Definitions, issues and its implications for english teachers. English Language Teaching, 3(4), 159-167. https://doi.org/10.5539/elt.v3n4p159

Crismore, A., Markkanen, R., \& Steffensen, M. (1993). Metadiscourse in persuasive writing: a study of texts written by written by American and Finnish university students. Written Communication, 10(1), 39-71. https://doi.org/10.1177/0741088393010001002

Heng, C. H., \& Tan, H. (2010). Extracting and comparing the intricacies of metadiscourse of two written persuasive corpora. International Journal of Education and Developement Using Information and Communication Technology (IJEDICT), 6(3), 124-146.

Hyland, K. (1998). Persuasion and context: The pragmatics of academic metadiscourse. Journal of Pragmatics, 30(4), 437-455. https://doi.org/10.1016/S0378-2166(98)00009-5

Hyland, K. (2004). Disciplinary interactions: Metadiscourse in L2 postgraduate writing. Journal of Second Language Writing, 13, 133-151. https://doi.org/10.1016/j.jslw.2004.02.001

Hyland, K. (2005). Metadiscourse: Exploring interaction in writing, continuum guides to discourse. London: Continuum

Hyland, K., \& Tse, P. (2004). Metadiscourse in academic writing: A reappraisal. Applied Linguistics, 25(2), 156-177. https://doi.org/10.1093/applin/25.2.156

Intraprawat, P., \& Steffensen, M. S. (1995). The use of metadiscourse in good and poor ESL essays. Journal of Second Language Writing, 4(3), 253-272. https://doi.org/10.1016/1060-3743(95)90012-8

Jalilifar, A., \& Alipour, M. (2007). How explicit instruction makes a difference: Metadiscourse markers and EFL learners' reading comprehension skill. Journal of College Reading and Learning, 38(1), 35-52. https://doi.org/10.1080/10790195.2007.10850203

Kumpf, E. P. (2000). Visual metadiscourse: Designing the considerate text. Technical Communication Quarterly, 9(4), 401-424. https://doi.org/10.1080/10572250009364707

Rashid, R. A., Rahman, M. F. A., \& Rahman, S. B. A. (2016). Teachers' engagement in social support process on a networking site. Journal of Nusantara Studies, 1(1), 34-45.

Rustipa, K. (2014). Metadiscourse in Indonesian EFL Learners' Persuasive Texts: A Case Study at English Department, UNISBANK. International Journal of English Linguistics, 4(1), 44-52. https://doi.org/10.5539/ijel.v4n1p44

Vande Kopple, W. (1985). Some exploratory discourse on metadiscourse. College Composition and Communication, 36, 82-93. https://doi.org/10.2307/357609

Williams, J. M. (1985). Style: Ten lessons in clarity and grace (2nd ed.). Glenview: Scott Foresman.

\section{Copyrights}

Copyright for this article is retained by the author(s), with first publication rights granted to the journal.

This is an open-access article distributed under the terms and conditions of the Creative Commons Attribution license (http://creativecommons.org/licenses/by/4.0/). 